\title{
Population aging in Brazil: current and future social challenges and consequences
}

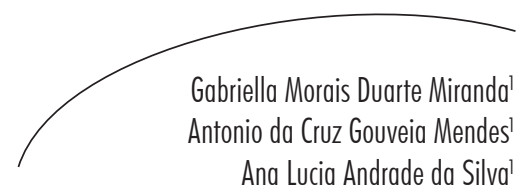

\section{Abstract}

Objective: To analyze the current and future challenges related to the planning of public policies and population aging. Method: A case study was conducted using quantitative and qualitative data from secondary data information systems and interviews with actors of social policy and the country's health. Results: In 2010, there were 39 elderly persons for every 100 young people, while in 2040 there will be an estimated 153 elderly persons for every 100 young people. For those interviewed, Brazil is not prepared for the needs generated by such population aging, due to challenges such as the adequacy of the social security and health system. The growing number of elderly persons and increasing morbidity and mortality profiles worsen the heterogeneous epidemiological situation with disease, disability and sequelae that require the health system to be a continuous and multidisciplinary organization. The present study identified a reduction of beds and hospitalizations, which may reflect the improvement of primary care and quality of life, with a complexification of hospitalizations. Conclusion: With population aging and a lack of necessary support, society must be aware of the price that it must pay and the state must be prepared to provide specific policies to ensure comprehensive care, recognizing the characteristics of aging and preserving quality of life.

Fundação Oswaldo Cruz, Centro de Pesquisas Aggeu Magalhães, Departamento de Saúde Coletiva. Recife, Pernambuco, Brasil.

This article is based on the thesis by the first author entitled: "Health and inequality: challenges for Brazil in a context of demographic and epidemiological transition and social change", defended in 2014, as part of the Post Graduate Program in Public Health of the Centro de Pesquisas Aggeu Magalhães da Fundação Oswaldo Cruz (the Aggeu Magalhães Research Center of the Oswaldo Cruz Foundation)."

Key words: Demographic Transition; Demographic Aging; Public Policies. 


\section{INTRODUCTION}

From 1970 onwards, the demographic profile of Brazil transformed from a mostly rural and traditional society with large families and a high infant mortality rate to a mostly urban society with fewer children and a new structure in Brazilian families. ${ }^{1}$ From a predominantly young population in the not so distant past, today an increasingly significant number of people aged 60 or older can be observed. $^{2}$

Demographic transition begins with a fall in mortality rates which is soon followed by falling birth rates, resulting in significant changes in the age structure of the population. ${ }^{3}$

These changes have occurred rapidly, requiring a quick and appropriate response that cannot take place without the intervention of the State through the establishment and implementation of fundamental public policies. ${ }^{4}$

Projections indicate that by 2050 "the Brazilian population will be 253 million, the fifth largest population in the world, smaller only than India, China, USA and Indonesia". This will be only 40 years after 2005, when the country's total fertility rate reached 2.1 children per woman (the level that represents sustainable zero population growth) and the true period of zero growth of the Brazilian population. ${ }^{5}$

Population aging increases health problems which in turn put pressure on healthcare and social security systems. Getting older does not necessarily mean becoming sick. Unless there are associated illnesses, aging is associated with a good level of health. Moreover, advances in the fields of health and technology allow people with access to adequate public or private services to have a better quality of life at this stage of life. In addition, it is essential to invest in preventive actions throughout the course of life due to their potential to "solve the challenges of today and, increasingly, those of tomorrow". ${ }^{6}$
It is for this reason that countries are increasingly seeking to understand the process of population aging and searching for alternatives to "keep their elderly citizens socially and economically integrated and independent". ${ }^{6}$ This is because the growing presence of elderly people in society imposes the challenge of including population aging in public policies and implementing actions of prevention and care to target their needs, thereby supporting a network with the capacity to offer services and actions of social protection.?

The proposal of the present study was to analyze the current and future challenges related to the planning of public policies and population aging, in a context of demographic transition and transformation of the demographic profile in the decades to come.

\section{METHOD}

A case study on population aging and its relation with the planning and formulation of public policies was carried out.

To characterize the scenario, secondary data from the main information systems in Brazil was utilized. To analyze the planning of public policies in the context of these transformations, eight people occupying relevant positions in social politics, health management and the legislative authorities were interviewed (a former national Health Minister, former secretaries of the Ministry of Health, and former state and municipal secretaries of health) in addition to intellectuals and planners from the area of health.

This study is an excerpt from a doctoral thesis on Public Health, which, as selection criteria to select participants, chose participants who had built their reputations in defense of the right to health, and who had been included in the political context and the organization of the country's health system since its inception. 
In addition to the population data, three demographic indicators relating to the period 1920-2040 were analyzed. Data on population, life expectancy at birth, the dependency ratio and the aging index were calculated based on the estimates and censuses conducted by the Instituto Brasileiro de Geografia e Estatística - IBGE (Brazilian Institute of Geography and Statistics).

For the dependency ratio and aging index, calculations proposed by the Rede Interagencial de Informações para a Saúde (Interagency Network of Information for Health) ${ }^{8}$ were used, considering the ratio between the number of people age 60 or above for every 100 people under 15 years of age and the ratio between the age segment of the population defined as economically dependent (people under 15 years of age and those aged 60 or more) and the potentially productive age segment (between 15 and 59 years of age), respectively.

According to the Interagency Network,${ }^{8}$ it is common for the calculation of these indexes to consider elderly people as those aged 65 and over and the potentially productive to be between 15 and 64 years of age. However, to maintain consistency with the other indicators and to comply with the National Policy for the Elderly (Law no. 8842 , of January 4, 1994), the parameters of 60 and over for the elderly population and 15 to 59 years of age for the potentially productive population were utilized.

The information regarding the number of active elderly beneficiaries and the value of benefits, over the period 2002 to 2012, were extracted from the Ministério da Previdência Social (Ministry of Social Security) (MPS). Active benefits were analyzed, meaning those considered by the MPS to actually generate monthly payments to the beneficiary. To analyze the variation of the amounts paid, a calculation of public spending was carried out considering the devaluation of the currency, using the Índice Nacional de Preços ao
Consumidor Amplo (National Index of Consumer Prices) (IPCA) from 2012, as a basis for calculation.

For the analysis of morbidity and mortality, standardized rates were calculated per 100,000 elderly people in each year studied. The five main chapters were chosen from the $10^{a}$ Revisão da Classificação Internacional de Doenças (10th Revision of the International Classification of Diseases) (CID-10), among the causes of hospitalization and death of the elderly. The technique of direct standardization by age was applied (60 to 69, 70 to 79 and 80 years and over), considering the resident population in the country in 2010 as standard.

The number of hospitalizations was obtained from the total of Autorização de Internação Hospitalar (Hospitalization Authorizations) (AIH) paid and registered in the Sistema de Informações Hospitalares (Hospital Information System) (SIH) of the Sistema Único de Saúde (National Health System) (SUS). The information is only related to hospitalizations in the SUS network and therefore, does not include hospitalizations that occurred in the supplementary system. Average values were calculated by means of the ratio between the amount paid by AIH and the number of hospitalizations, and were updated according to the IPCA (National Index of Consumer Prices) of the year, 2013.

The number of hospital beds available through the SUS (National Health System) only was obtained from the monthly records of the Ministry of Health, and an annual average was calculated from this data. For the years 1998 - 2003, data recorded in the SUS archived records (Cadastro Hospitalar-CH) (Hospital Registry) was used, provided by the IT Department of SUS (Datasus). For the other years of the series, data was acquired from the Cadastro Nacional de Estabelecimentos de Saúde (National Registry of Health Facilities) (CNES). 
To verify the seasonal tendency of the variables, linear trend analysis was used. Simple linear regression models were estimated, defined as $\mathrm{Y}=\alpha+\beta$ year, $\alpha$ being the mean coefficient in the analyzed period and $\beta$ the mean increment (increase or decrease) in the period. The coefficient of determination R2 indicated the explanation capacity of the model. All decisions were made considering a statistical significance level of 5.0\%.

To conduct, carry out and analyze the interviews that took place between June and July of 2015, the seven stages of research proposed by Kvale were applied. ${ }^{9}$ The content of the interviews was defined based on the conceptual framework of universalization, social control, financing of needs and the decentralization of the SUS (National Health System).

The analysis of each question in the interviews was carried out using the meaning condensation technique, where formulations were constructed based on the responses of each of the respondents, the units of natural meanings are determined based on the content expressed by each subject, the core issues are determined in relation to the natural units and an essential description of the themes identified in the interview is performed, as defined by Kvale.?

The research complied with ethical standards and the databases are public domain, requiring publication of the source of data. In addition, the doctoral thesis project that resulted in this article was submitted to and obtained approval from the Research Ethics Committee of the Aggeu
Magalhães Research Center of the Oswaldo Cruz Foundation in Recife, Pernambuco (Registration no: CAAE: 21258713.0.0000.5190).

\section{RESULTS AND DISCUSSION}

The elderly population is rising dramatically in Brazil, based on the concept of the World Health Organization which considers a person to be elderly at 60 years of age or older if residing in a developing country. In 1920, life expectancy was only 35.2 years and the elderly accounted for just $4.0 \%$ of the total population of the country. With this profile, for every 100 children (0 to 14 years of age), Brazil had approximately 11 elderly people (table 1).

In 2010 (table 1), with the doubling of life expectancy (almost 74 years of age), 10.8\% of the population was 60 years of age or above, gradually increasing the relative proportion of elderly people in the age composition of the country. Associated with this, there is an increase in the aging index and a reduction in the dependency ratio.

Population estimates by the IBGE (Brazilian Institute of Geography and Statistics) indicate that the participation of elderly people will reach approximately $23.8 \%$ of the population in the fifth decade of the $21^{\text {st }}$ century. With the number of elderly people increasing in relation to the young, it is estimated that there will be an inversion of the relation between young and old, with 153 elderly people for every 100 people under 15 years of age (table 1). 
Table 1. Estimate of the Brazilian population and demographic characteristics between the years 1920 and 2040. Recife-PE, 2015.

\begin{tabular}{lccccc}
\hline \multicolumn{1}{c}{ Age group } & 1920 & 1950 & 1980 & 2010 & 2040 \\
\hline 0 to 4 years & 4.593 .163 & 8.370 .880 & 16.423 .700 & 13.796 .159 & 11.267 .417 \\
5 to 9 years & 4.575 .530 & 7.015 .527 & 14.773 .741 & 14.969 .375 & 11.813 .256 \\
10 to 14 years & 3.909 .630 & 6.308 .567 & 14.263 .322 & 17.166 .761 & 12.360 .437 \\
15 to 19 years & 4.217 .917 & 5.502 .315 & 13.575 .971 & 16.990 .870 & 13.019 .512 \\
20 to 24 years & 2.139 .364 & 4.991 .139 & 11.513 .220 & 17.245 .190 & 13.717 .223 \\
25 to 29 years & 2.487 .431 & 4.132 .271 & 9.442 .217 & 17.104 .413 & 14.514 .616 \\
30 to 39 years & 3.560 .225 & 6.286 .052 & 14.039 .109 & 29.633 .093 & 31.914 .624 \\
40 to 49 years & 2.401 .200 & 4.365 .359 & 10.377 .274 & 24.842 .718 & 32.893 .266 \\
50 to 59 years & 1.451 .319 & 2.650 .314 & 7.250 .094 & 18.416 .621 & 32.447 .959 \\
60 to 69 years & 800.866 & 1.451 .468 & 4.474 .511 & 11.349 .929 & 25.811 .887 \\
70 years or more & 433.310 & 753.873 & 2.741 .506 & 9.240 .670 & 28.393 .007 \\
Life expectancy at birth & 35.2 & 52.3 & 64.7 & 73.9 & 79.9 \\
Dependency rate & 89.0 & 85.6 & 79.6 & 55.2 & 64.7 \\
Aging index & 10.6 & 10.2 & 15.9 & 39.3 & 152.9 \\
\hline
\end{tabular}

Source: IBGE (2015).

The transition in birth and mortality rates, from high to low, made major changes in population structure part of the demographic transition debate. $^{2}$ These changes have occurred quickly, "requiring rapid and adequate adaptations that will not take place without State intervention through fundamental public policies". ${ }^{4}$

The country is aging at an alarming pace. Changes in population structure are clear and irreversible. Since the 1940s, the highest rates of population growth have been observed among the elderly. ${ }^{10}$ This growth of the elderly population generates a series of changes in society, related to the economic sector, the labor market, the health systems and services and family relations. ${ }^{11,12}$

Contrary to what has occurred in many developed countries, in Brazil, as seen in this text, the aging process has been extremely rapid. In the interviews carried out, it was affirmed that the country is not prepared to meet the needs generated by this aging of the population. According to one of the interviewees, only in recent years has the country directed its efforts to long-term policies, while being faced with emergency demands at the same time.

"In fact, Brazil started to have a vision and a concern for the long term...to plan ahead, following the installation of the Lula government, which on the other hand found itself dealing with a contingency that resulted in an emergency strategy to promote social inclusion [...]”. (Interviewee 7)

According to the World Health Organization, ${ }^{13}$ the aging of the population is one of the greatest triumphs of humanity and yet also one of the major challenges to be faced by society. In the $21^{\text {st }}$ century, aging will increase social and economic demands across the world. However, despite being greatly ignored, the elderly should be considered essential to the structure of societies. 
In its report on aging in the 21st century, the United Nations Population Fund ${ }^{14}$ stressed that although many countries have made substantial progress in adapting their policies and laws, it is necessary to direct more efforts to ensure that older people can reach their potential.

There was consensus among the interviewees that an aging population requires the urgent introduction of policies appropriate to their needs. The growth of the elderly population and increased life expectancy at birth, already discussed, represent major challenges for the country. Some interviewees pointed out, for example, the challenge to be faced by the social security system to adapt to the new demographic reality of Brazil.

"[...] probably we will be called upon to promote major reforms in the structure of the Brazilian state, especially in the area of social security, in relation to bealth. For the system to better adapt to the process of aging of the population". (Interviewee 7)

"[...] surely changes will be demanded from society in terms of retirement schemes. Brazil has already implemented some changes and these are objects of great political debates, but surely, you can't maintain the same social security system created for a society in which life expectancy was 55 years, for a society with a life expectancy of 75 years of age [...]”. (Interviewee 2)

The number of elderly grew $40.3 \%$ between 2002 and 2012. In the same period, the number of active benefits, with the exception of pensions granted by the Ministry of Welfare, expanded by $55.3 \%$. In current values, the significant increase $(\mathrm{p}<0.05)$ represented an expansion of nearly $146.0 \%$ in public spending in the period (table 2).

Table 2. Evolution of population, number and updated values of active benefits of Brazilian elderly between 2002 and 2012. Recife-PE, 2015.

\begin{tabular}{cccc}
\hline Year & \multicolumn{3}{c}{ Elderly People } \\
\cline { 2 - 4 } & Population & $\begin{array}{c}\text { Active } \\
\text { benefits }\end{array}$ & Updated values $(\mathrm{R} \$)^{*}$ \\
\hline 2002 & $14,887,348$ & $10,112,887$ & 5.52 \\
2003 & $15,050,492$ & $10,526,480$ & 6.27 \\
2004 & $15,212,532$ & $11,184,357$ & 6.68 \\
2005 & $15,581,260$ & $11,652,478$ & 7.29 \\
2006 & $15,769,169$ & $12,165,960$ & 8.18 \\
2007 & $18,204,829$ & $12,674,963$ & 8.74 \\
2008 & $18,761,039$ & $13,288,644$ & 9.31 \\
2009 & $19,428,086$ & $13,890,631$ & 10.25 \\
2010 & $20,590,599$ & $14,495,960$ & 11.73 \\
2011 & $20,742,226$ & $15,045,858$ & 12.33 \\
2012 & $20,889,849$ & $15,707,685$ & 13.57 \\
\hline
\end{tabular}

*Value updated in billions.

Source: IBGE (2015), Ministry of Social Security (2015). 
This scenario of rapid aging has generated considerable pressure on the pension system, which had been organized to meet a demand represented by the increase in official employment and the brevity of the retirement period. The changes that have taken place in the demographic structure, have increased the pressure on social protection systems, mainly due to the fall in the number of the contributing population in relation to the increasing number of those who retire.

According to Costa et al. ${ }^{15}$ it is "essential to restructure the pension system in order to ensure its sustainability", due to the increase of the beneficiary population and the aging and reduction of the workforce.

In 2010, as previously mentioned, there were 20.5 million elderly people in the country, approximately 39 for every 100 young people. It is estimated that in 2040, this number will have doubled, representing $23.8 \%$ of the population and a ratio of almost 153 elderly people for every 100 young people. This new demographic reality, with a constantly growing number of elderly people, also requires that the health system has the capacity to respond to current and future demands.

".... A population that lives longer and with low quality of life tends to put pressure on the health system by demanding more expensive, more specialized services, and we are not preparing for this". (Interviewee 1)

"[...] now is the time for the bealth system to structure itself for this growing demand of the elderly population. [...] because you are presented with a growth in the number of degenerative diseases that require coordinated actions by different professionals. So the preparation of the health system as a whole to meet this growing demand is a major challenge". (Interviewee 3)

In addition, elderly people can acquire disease, disabilities and sequelae that require integrated actions in the health system. As previously analyzed, the results related to morbidity and mortality rates show part of the complex epidemiological profile experienced by Brazilian society (table 3 ). 


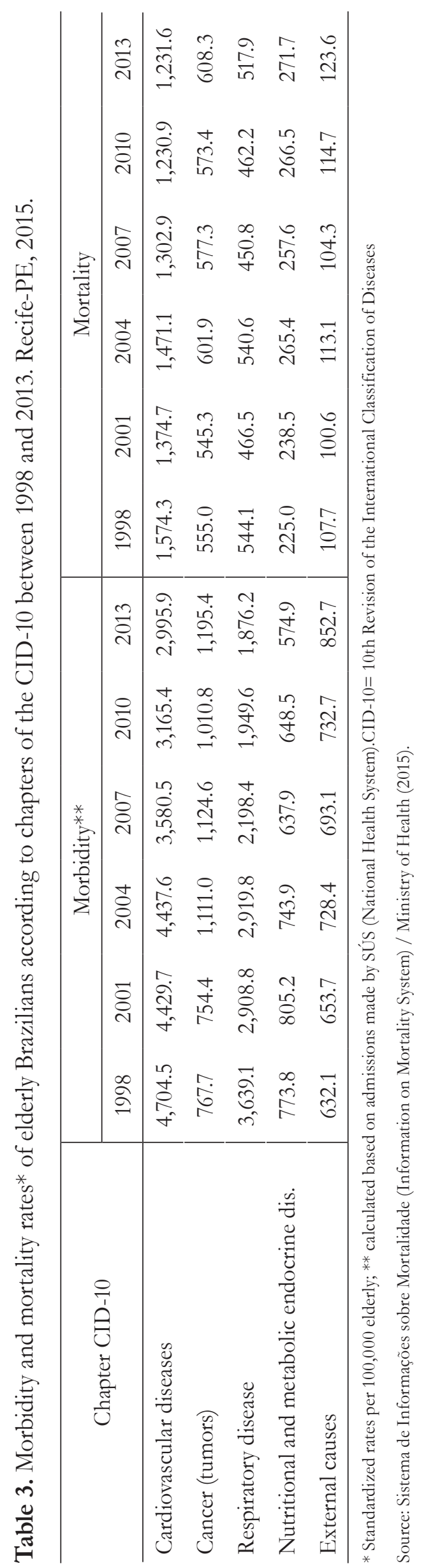


Although they are still the cause of a significant number of hospital morbidities among the elderly in Brazil, a reduction in hospitalizations due to cardiovascular illnesses, respiratory and nutritional and metabolic endocrine diseases can be observed. This decrease may reflect the expansion and improved quality of primary care services in the country. On the other hand, a significant and growing number of hospitalizations due to cancer and external causes was identified, demonstrating the heterogeneous epidemiological scenario of Brazil.

The variation in mortality rates also showed a significant trend $(p<0.05)$, however, only deaths from cardiovascular and respiratory diseases presented a decrease during the study period, with an increase in deaths from cancer, external causes and endocrine and nutritional diseases. This profile represents a major challenge, especially with rapid population aging, as according to Omram, ${ }^{16}$ in the third stage of the epidemiological transition, the main causes of death are non-communicable chronic diseases such as heart and cerebrovascular diseases and cancers that tend to cause death close to the age believed to be the end of the biological life limit.

According to Schimdt et al., ${ }^{17}$ noncommunicable chronic diseases are currently the main priority for the health sector in Brazil. The country has introduced significant policies related to preventative actions, but due to the behavior and history of most risk factors, the challenge remains to carry out timely actions and introduce policies to deal with this problem.

Dealing with this complex profile of necessities requires a continuous and multidisciplinary organization of care from the health system, updating the work process, ensuring that health services and actions are carried out that promote the health and well-being of this elderly population on a permanent basis. This is mainly because of the association between the aging population and the increased demand for specialist and high cost care.

Among the elderly, although there are those who are healthy, many others have chronic illnesses and/or disabilities, resulting in an increase in the demand for health care, which due to their needs, is more expensive and specialized. The elderly population requires specific care, often specialized and directed towards the peculiarities that arise from the aging process, without segregating them from the society. ${ }^{18-20}$

One of the types of assistance, hospital care, should therefore be organized to meet the needs generated by this aging population. The analysis of bed usage and hospital admissions presented a significant variation $(p<0.05)$, verifying the tendency of increasing demand for surgical care and a reduction in demand for internal medicine over the years. (table 4).

The total number of beds and hospital admissions underwent a reduction in the period analyzed. While the total number of beds decreased 34.1\% between 1998 and 2013, there was also a decrease of $5.9 \%$ in hospital admissions, during a period when there was a population growth of $24.3 \%$ (39 million) and $54.3 \%$ of the elderly population. The exception was the growth in ICU beds $(86.1 \%)$ and admissions for surgical care.

In relation to internal medicine, a reduction of $4.6 \%$ was registered in the number of admissions and a decrease of $28.2 \%$ in the number of beds, although the elderly population increased during this the period. In relation to the number of surgical admissions, there was an increase of $44.1 \%$ throughout the period, accompanying the growth of the population, although there was a reduction of $18.6 \%$ in the number of beds. 
Table 4. Registered beds and hospitalizations between 1998 and 2013 in SUS*. Recife-PE, 2015.

\begin{tabular}{lcccccc}
\hline \multicolumn{1}{c}{ Variable } & 1998 & 2001 & 2004 & 2007 & 2010 & 2013 \\
\hline Total beds & 490.4 & 486.5 & 362 & 349.2 & 336.5 & 323.0 \\
ICU beds & 10.1 & 11.1 & 13.5 & 11.8 & 15.8 & 18.8 \\
Total admissions & $12,248.60$ & $12,227.20$ & $11,953.90$ & $11,739.30$ & $11,724.80$ & $11,520.80$ \\
\hline Internal medicine beds & 147.3 & 146.8 & 103.3 & 108.2 & 105.6 & 105.8 \\
Internal medicine admissions & $4,216.50$ & $4,123.10$ & $3,878.10$ & $3,806.90$ & $4,097.10$ & $4,021.6$ \\
\hline Surgical care beds & 93.1 & 95.3 & 77.1 & 75.8 & 76.5 & 75.8 \\
Surgical care admissions & $2,398.70$ & $2,644.00$ & $3,021.80$ & $3,214.30$ & $3,330.30$ & $3,455.5$ \\
\hline
\end{tabular}

*Beds and admissions per thousand.

Source: Hospital Information System/Ministry of Health (2015); National Register of Health Facilities/Ministry of Health (2015).

Despite the population growth, especially in the elderly population, the study found a reduction of beds and admissions. This data points to a possible explanation: the reduction of admissions may be related to the improvement in the quality of life of the elderly and consequently, the reduction in the need for hospitalization of this population. One complicating factor, however, is the increase in the average cost of hospitalization (table 5).

In a study of the health tendencies of the Brazilian elderly population using data from the Pesquisa Nacional por Amostra de Domicílios (National Survey by Sample of Households), LimaCosta et al. ${ }^{21}$ identified improvements in some aspects of the health of the elderly, such as the reduction of hospitalizations. For the authors, the results corroborate the expansion of primary care in the country.

In 2013, hospital care for the elderly accounted for $31.6 \%$ of public spending on admissions (table 5). Despite the relative increase in the cost of hospital care, it is a small growth, considering the rapid increase in the population, which as seen in this text, can present chronic disease, disability and sequelae that require continuous, specialized and qualified attention and care.

Between 1998 and 2013 there were almost 38 million hospital admissions of elderly people in the SUS, approximately 152 hospitalizations for every group of 1,000 elderly. Despite the absolute growth, a reduction was seen in the number of hospitalizations per thousand elderly persons in this period.

Table 5. Characteristics of hospital admissions of elderly Brazilians in SUS between 1998 and 2013. Recife-PE. 2015.

\begin{tabular}{lcccccc}
\hline \multicolumn{1}{c}{ Variables } & 1998 & 2001 & 2004 & 2007 & 2010 & 2013 \\
\hline Admissions & $2,139,007$ & $2,240,418$ & $2,324,573$ & $2,385,368$ & $2,518,002$ & $2,664,080$ \\
Total value (R\$)* & 845.15 & $1,216.57$ & $1,672.59$ & $2,019.72$ & $3,062.43$ & $3,971.82$ \\
Admissions /1,000 elderly & 168.37 & 152.18 & 152.81 & 131.03 & 122.29 & 120.67 \\
Average updated value (R $\$)$ & $1,027.77$ & $1,139.92$ & $1,143.71$ & $1,180.54$ & $1,447.80$ & $1,490.88$ \\
Proportion of values paid ** & 22.2 & 23.9 & 25.4 & 26.5 & 28.6 & 31.6 \\
\hline
\end{tabular}

*Total value $(\mathrm{R} \$)$ in millions; ${ }^{* *}$ proportion of values paid: considered as the proportional relation between the total value paid related to elderly admissions and the total value paid for all SUS admissions. 
In the assessed period, all the hospitalizations represented a cost of more than $\mathrm{R} \$ 33$ billion to the public health system in the country. In addition, the average cost of admissions increased significantly, demonstrating the expansion of spending and suggesting greater complexity of care. When compared with the first year studied, the average cost of admissions, corrected according to inflation, increased by more than $45.0 \%$.

This greater complexity reinforces the need for greater investment in the health system, as according to interviewee 1 , "the manner that the country will deal with this population, from a public health point of view, will depend a lot on additional 'heavy' expenditure in the system".

This scenario demonstrates the need to carry out actions to promote health and the prevention of illness, in order to prevent or delay chronic diseases and disabilities. One interviewee also pointed out the fragility of actions promoting health in the SUS, by recalling the concept of healthy cities and how they could promote the quality of life of the population.

"We don't have, for example, public health campaigns, or else they are insufficient to strongly encourage the population to adopt healthy life styles, to adhere to bealthy public health policies, policies that promote health [...] The promotion of health some years ago, seven or eight years ago, was more effective in the context of the health policies of the country than today". (Interviewee 1)

From the point of view of health policy, it is essential that the health system carries out actions covering all levels of care, considering both the prevention and treatment of chronic diseases that can affect the elderly. Thus, it is necessary that the health model goes beyond biological characteristics and through social determination, considers care in a broader perspective, including all the factors involved in the profile of the health of the elderly.

Preventive actions are effective at any level, even if carried out in the later stages of life. Therefore, "a model of health care for the elderly that intends to be effective and efficient must strengthen all levels of prevention".11
However, according to Küchemann, ${ }^{10}$ coverage is still insufficient in relation to services and accommodation for long-term care. There are few spaces that offer full-time care, such as homes or recreation centers and these are restricted to higher socioeconomic sectors, able to afford such services.

This means that to meet the demand generated by this aging population, it is necessary to establish mechanisms to strengthen the model of health care for the elderly, including investing in the workforce and the training of professionals so they will have the skills necessary for the prevention, care and comprehensive health care of the elderly.

"The care of these elderly people depends on human care, health depends on health professionals, education depends on [professionals], and so on, rebabilitation depends on equipment, but also on people. So, we need a policy of appropriate personnel, we need to have adequate performance from these professionals, who are not bureaucrats, not aggressive, but who invest in the autonomy of the elderly [...]”. (Interviewee 7)

"For this we have to prioritize the study of Geriatrics, Gerontology in higher education institutions and it is not prioritized. So there is a lot to do, before reality comes and overwhelms us and we are forced to chase after better conditions". (Interviewee 4)

Queiroz et al. ${ }^{22}$ recognized that there is a lack of specialized human resources to adequately meet the needs of this population, showing the importance of essential training projects aimed at professionals working in services and care for the elderly.

This deficiency justifies the need for investment in quantitative and qualitative training of professionals able to attend this population. The training of health professionals should consider an overall interdisciplinary approach in an integrated manner with the other practices of the social care network. $^{23}$

The issue demands urgent attention. According to Wong \& Carvalho, ${ }^{24}$ "investments in human resources training for geriatric and gerontological services take considerable time to show results".

Rather than being treated as a problem, the increase of human longevity should be a cause 
for celebration. ${ }^{25}$ The data demonstrates that Brazil's demographic transition represents both an achievement and a responsibility for public administration and society. It is essential to make investments that strengthen autonomy and promote healthy lives for elderly people, as well as ensuring adequate care for their needs. In order to do this, it is vital to direct the planning of policies and services. After all, from today onwards, the elderly population will increase until the year $2050 .{ }^{26}$

The question, therefore, is not related to the interpretation of from what age the health system should intensify its intervention, but what kind of life the health system should protect and wants to protect. ${ }^{27}$ After all, we should celebrate aging and "the increase in life expectancy is a triumph of development". ${ }^{28}$

Studies that utilize secondary data as their source may have limitations due to issues related to data processing. The richness of the discussions was only possible because the data was related to the perception of important social players, who experience the struggle for social justice in their day-to-day lives.

It is important that further studies are carried out to analyze the evolution of socioeconomic conditions and health care, the current demographic transition and the new epidemiological profile and the demands it presents for the country.

\section{REFERENCES}

1. Leone ET, Maia AG, Baltar PE. Mudanças na composição das famílias e impactos sobre a redução da pobreza no Brasil. Econ Soc 2010;19(1):59-77.

2. Vasconcelos AMN, Gomes MMF. Transição demográfica: a experiência brasileira. Epidemiol Serv Saúde 2012;21(4):539-48.

3. Alves JED. A transição demográfica e a janela de oportunidade. São Paulo: Instituto Fernand Braudel de Economia Mundial; 2008.

\section{CONCLUSION}

The challenge of aging must be urgently confronted. The country already has a significant percentage of elderly people, which will increase in the coming years, demanding specialized public services that will reflect the current planning and priorities of public social policies. It is essential, therefore, that these policies have integrated interventions that ensure the necessary care for chronic diseases, but which strengthen the promotion of healthy aging.

The country must, in addition to reorganizing levels of care to meet these necessities, also innovate and use as a base experiences from other countries that have experienced the aging process.

With an aging population and a lower ratio between the active and dependent population, without family networks capable of supporting the elderly and lacking support structures for this population, society must be aware of the price it will have to pay and the increasing cost of care of the elderly population. Moreover, the State should be prepared for the provision of specific policies for the financing of support structures as well as for monitoring its own activities. This will ensure comprehensive care, recognizing the characteristics and specificities of the elderly and consecrating their quality of life. This is the challenge for society and government in the coming decades.

4. Brito F. A Transição demográfica e as políticas públicas no Brasil: crescimento demográfico, transição da estrutura etária e migrações internacionais [Internet]. Brasília, DF: SAE; 2007 [acesso em 16 abr 2013]. Disponível em: www.sae. gov.br/site/wp-content/uploads/07demografia1.pdf

5. Brito F. Transição demográfica e desigualdades sociais no Brasil. Rev Bras Estud Popul 2008; 25(1):5-26.

6. Kalache A. O mundo envelhece: é imperativo criar um pacto de solidariedade social. Ciênc Saúde Coletiva 2008;13(4):1107-11. 
7. Batista AS, Jaccoud LB, Aquino L,El-Moor PD. Envelhecimento e dependência: desafios para a organização da proteção social. Brasília, DF: MPS, SPPS; 2008.

8. Rede Interagencial de Informação para a Saúde. Indicadores e dados básicos para a Saúde no Brasil (IDB) [Internet]. Brasília, DF: Ministério da Saúde; 2014 [acesso em 20 jun. 2014]. Disponível em: http:// tabnet.datasus.gov.br/cgi/idb2012/matriz.htm

9. Kvales S. An introdution to qualitative research interview. Thousand Oaks: SAGE Publications; 1996.

10. Küchemann BA. Envelhecimento populacional, cuidado e cidadania: velhos dilemas e novos desafios. Soc Estado 2012; 27(1):165-80.

11. Veras R. Envelhecimento populacional contemporâneo: demandas, desafios e inovações. Rev Saúde Pública 2009;43(3):548-54.

12. Veras RP, Caldas CP. Promovendo a saúde e a cidadania do idoso: o movimento das universidades da terceira idade. Ciênc Saúde Coletiva 2004;9(2):423-32.

13. Organização Mundial da Saúde. Envelhecimento ativo: uma política de saúde. Brasília, DF: OPAS; 2005.

14. Fundo de população das nações unidas. Resumo Executivo. Envelhecimento no Século XXI: celebração e Desafio. New York; 2012.

15. Costa CKF, Mesquita RA, Porto SS Junior, Massuda EM. Envelhecimento populacional e a necessidade de reforma da saúde pública e da previdência social brasileiras. Econ Rev 2011;19:121-31.

16. Omram AR. The epidemiologic transition: a theory of the epidemiology of population change. Milbank Q 2005; 83(4):731-57.

17. Schimdt MI, Duncan BB, Azeedo e Silva G, Menezes AM, Monteiro CA, Barreto SM, et al. Doenças crônicas não transmissíveis no Brasil: carga e desafios atuais. Lancet 2011;377:61-74.
18. Bergmark A, Parker MG, Thorslund M. Priorities in care and services for elderly people: a path without guidelines? J Med Ethics 2000;26:312-8.

19. Mendes MRSSB, Gusmão JL, Mancussi e Faro AC, Leite RCBO. A situação social do idoso no Brasil: uma breve consideração. Acta Paul Enferm 2005;18:422-6.

20. Ribeiro CDM, Schramm FR. A necessária frugalidade dos idosos. Cad Saúde Pública 2004;20(5):1141-59.

21. Lima- Costa MF, Matos DL, Camargos VP, Macinko J. Tendências em dez anos das condições de saúde de idosos brasileiros: evidências da Pesquisa Nacional por Amostra de Domicílios (1998, 2003, 2008). Ciênc Saúde Coletiva 2011;16:3689-96.

22. Queiroz ZPV, Ruiz CR, Ferreira VM. Reflexões sobre o envelhecimento humano e o futuro: questões de ética, comunicação e educação. Rev Kairós 2009;12:21-37.

23. Motta LB, Aguiar AC. Novas competências profissionais em saúde e o envelhecimento populacional brasileiro: integralidade, interdisciplinaridade e intersetorialidade. Ciênc Saúde Coletiva 2007;12:363-72.

24. Wong LLR, Carvalho JA. O rápido processo de envelhecimento populacional do Brasil: sérios desafios para as políticas públicas. Rev Bras Estud Popul 2006;23:5-26.

25. Lloyd- Sherlock PL, MCKee M, Ebrahim S, Gorman M, Greengross S, PRINCE M, et al. Population ageing and health. Lancet 2012;379:1295-6.

26. Minayo MCS. O envelhecimento da população brasileira e os desafios para o setor saúde. Cad Saúde Pública 2012;28:208-9.

27. Diniz D, Medeiros M. Envelhecimento e alocação de recursos em saúde. Cad Saúde Pública 2004;20:1154-5.

28. Help Page International. Índice Global del Envejecimiento: Resumen [Internet]. Madrid; 2013 [acesso em 18 set. 2014]. Disponível em: http://www. helpage.es/noticias/helpage-international-presenta-elprimer-ndice-global-del-envejecimiento/ 